\title{
Osmanlı Basınında İntihale Dair Bazı Örnekler ve Yaşanan Tartışmalar*
}

\section{Examples and Debates Related to Plailailsm in the Ottoman Press Hilstory}

\section{Ahmet Ali Gazel}

Türkçe ve Sosyal Bilgiler Eğitimi Bölümü, Afyon Kocatepe Üniversitesi, Afyonkarahisar, Türkiye

\begin{abstract}
Özet
İkinci Meşrutiyet'in ilanından sonra Osmanlı Devleti'nde birçok gazete ve dergi yayın hayatına girmiştir. Belirtilen dönemde Osmanlı Devleti'nde haber ajanslarının olmaması gazete ve dergilerin kendi imkânlarıyla haber toplamalarını gerekli kılmışıı. Bu nedenle gazeteler muhabirlerinin getirdikleri haberler yanında diğer gazeteleri de tarayarak atladıkları veya atlatılıkları haberleri buralardan temin etme yoluna gitmişlerdir. 0 tarihlerde gazetelerin akşam veya sabah gazetesi olarak çıkmaları da bu işi kolaylaştırmıştır.

Gazetelerin 1910 yılına kadar birbirlerinden kaynak göstermeden haber alabilmelerini kolaylaştıran unsurlardan biri de telif hakları konusundaki hukuki boşluktu. 1910 yılında yasalaşan Telif Kanunu ile gazetelerden alınan haberlere de kaynak gösterme zorunluluğu getirilmiştir. Buna rağmen gazeteler birbirlerinden kaynak göstermeden haber almaya devam etmişlerdir. Ancak her gazete bu durumdan şikâyet etmemiş ise de zaman zaman bu işten rahatsız olan gazeteler de olmuştur. Bizim tespit edebildiğimiz kadarıyla Osmanlı Basın Tarihinde bu konuyla ilgili üç tartışma yaşanmıştır. Bunların birincisi 1910 yııında Tanin ile Sabah arasında, ikincisi yine 1910 yılında İkdam ile yine Sabah arasında, üçüncüsü ise 1921 yılında Vakit ile Peyam-ı Sabah arasında yaşanmıştır. Bu üç hadise gazeteler arasında yapılan bir tartışma ve teşhir şeklinde kalmış, hukuki bir süreç yaşanmamıştır.

Bu bildiride yukarda belirtilen üç hadise dönemin gazetelerine dayalı olarak anlatılmıştır.

Anahtar Kelimeler: Osmanlı Basını, İntihal, Tanin, Vakit, Sabah, İkdam.
\end{abstract}

\section{Abstract}

After the second constitutionalist period, numerous newspapers and magazines began their broadcasting life in Ottoman Empire. Because there were not any press agencies in Ottoman Empire in that time, employees of newspapers and magazines had to collect information with their own means. For this reason, editorial boards of newspapers and magazines screened other newspapers in order to find the news that was missed or they missed. One of the things making this situation easier was that newspapers were published twice a day (morning and evening) in that time.

Another ease for collecting news from other newspapers without providing reference was the legal gap. Providing reference in news taken from other newspapers had been obligatory with the Copyright Law put into action in 1910. However, newspapers kept on taking news from other newspapers without giving any reference. Although not all newspapers' boards did complain, some newspaper boards were uncomfortable with that situation. There were three arguments encountered in Ottoman Empire that we could detect. First argument was encountered between Sabah and Tanin in 1910, second argument was between Ikdam and Sabah again in 1910, and the third argument was Vakit and Peyam-I Sabah in 1921. These three cases were defined as arguments and exposures. So, there were not any judicial processes.

In this paper, those three cases were introduced based on the data of newspapers of that time.

Key Words: Ottoman Press, Plagiarism, Tanin, Vakit, Sabah, Ikdam.

* Bu çalışma Atatürk Araştırma Merkezi tarafından 19-21 Ekim 2016 tarihleri arasında Elazı̆̆’da düzenlenen Türk Basın Tarihi Uluslararası Sempozyumda sunulan bildirinin gözden geçirilmiş halidir.

CONTACT : Ahmet Ali Gazel, agazel@aku.edu.tr, ORCID ID: orcid.org/0000-0002-7211-6032

Geliş Tarihi \& First Received : 08.08.2017

Kabul Tarihi \& Accepted $\quad$ : 16.10.2017 


\section{GíRİ̧}

İkinci Meşrutiyet'in ilanından sonra Osmanlı Devleti'nde birçok gazete ve dergi yayın hayatına girmiştir. Belirtilen dönemde Osmanlı Devleti'nde haber ajanslarının yetersiz olması gazete ve dergilerin özellikle iç haberleri kendi imkânlarıyla toplamalarını gerekli kılmıştır. ${ }^{1}$ Ancak gazetelerin çoğu maddi imkânsızlıklar nedeniyle ülke içinde tam olarak bir haber örgütü kuramamışlardır. ${ }^{2} \mathrm{Bu}$ nedenle gazeteler, kendi muhabirlerinin getirdikleri haberler yanında diğer gazeteleri de tarayarak atladıkları veya atlatıldıkları haberleri buralardan "aşırma" yoluna gitmişlerdir. O tarihlerde gazetelerin akşam veya sabah gazetesi olarak çıkmaları da bu işi kolaylaştırmıştır.

Gazetelerin birbirlerinden kaynak göstermeden haber alabilmelerini kolaylaştıran unsurlardan biri de telif hakları konusundaki hukuki boşluktu. Zira Osmanlı Devleti'nde 21 Mayıs 1910 tarihli Telif Kanunu'na kadar telif hakları açısından süreli yayınlarla ilgili hukuki bir boşluk bulunmaktaydı. Osmanlı'da telif haklarına ait ilk ana mevzuat 1857 tarihli Telif Nizamnamesidir. 1870 yılında da Telif Nizamnamesini tamamlayıc1 şekilde Telif ve Tercüme Nizamnamesi yürürlüğe konulmuştur. ${ }^{3}$ Ancak bu nizamnamelerde süreli yayınlarla ilgili bir mevzuat bulunmamaktadır. Süreli yayınlardaki telif haklarıyla ilgili ilk mevzuat 21 Mayıs 1910 tarihinde yürürlüğe giren Telif Hakları Kanunu ile olmuştur. "Her nevi mahsulat-1 fikriye ve kalemiye üzerinde sahiplerinin bir hakk-1 temellükü vardır. Bu hakka hakk-1 telif denilir" şeklinde ilk defa telif hakkı kavramının tanımının yapıldı ${ }_{1}^{4}$ Telif Kanunu'nun 4. maddesinde "Matbuat-1 yevmiye ve mevkutede 'hakkı mahfuzdur' ve 'aheri tarafından neşr ve tercümesi memnudur' gibi bir kayd ile neşr olunan makalatın ve tersimatın hakkı mahfuzdur. Fakat böyle bir kayd ile mukayyet olmayan makale ve resimlerle havadis ve şuun-1 yevmiye üzerinde me'haz gösterilmek şartıyla hakk-1 telif yoktur" denilerek süreli yayınlarla ilgili telif hakları düzenlenmiştir. Telif Kanunu'nun 32. maddesinde ise kanuna uymayanlara verilecek ceza belirtilmiştir. Maddeye göre telif hakkı bulunan eserleri sahiplerinin izni olmadan basan ve bastırandan yirmi beş Osmanlı altınından

\footnotetext{
${ }^{1}$ Osmanlı gazeteleri dış haberleri yabancı haber ajanslarından (Havas, Reuter, Corrbureau, Continental, Constantinople), İstanbul'da yabancı dilde yayımlanan ve Beyoğlu gazeteleri diye bilinen gazete ve dergilerden ve yurt dişında yayımlanan gazete ve dergilerden temin etmişlerdir. Bkz. Filiz SeçimSeyfettin Turhan, Haber Ajansları, Eskişehir 1994, s. 17-18; Osmanlı'da ilk yerli ajans, 1911 yılında Salih Gürcü tarafından kurulan Osmanlı Telgraf Ajansı'dır. Havas ve Reuter'in örtülü bir örgütü olan bu ajans İngiliz ve Fransız hükümetlerinin propagandasını yaptığı gerekçesiyle 1914 yılında kapatılmış ve yerine Osmanlı Milli Telgraf Ajansı kurulmuştur. Bu ajans daha çok Alman haber alma servislerinden alınan bültenleri yayınlamıştır. I. Dünya Savaşı sonunda bu ajans da kapanmıştır. 1920'de Türkiye'ye yerleşen yabancılar Türkiye'de kendi haberlerini yayacak bir ajans kurmak istemişler, neticede 1920 yılında Türkiye-Havas-Reuter Ajansı kurulmuştur. Bu ajansın Türkiye ile isim dışında herhangi bir bağlantısı yoktur. Türkiye'nin ilk haber ajansı 6 Nisan 1920 tarihinde Ankara'da kurulan Anadolu Ajansı'dır. Bkz. Hıfzı Topuz, 100 Soruda Türk Basın Tarihi, İstanbul 1996, s. 68-69.

2 II. Abdülhamit döneminde en fazla siyasi haber yayınlayan gazete İkdam olmuştur. Bunun nedeni gazetenin kendine ait bir telgraf hattı olması, ayrıca Paris’te bir muhabirinin bulunmasıydı. Bkz. SeçimTurhan, age., s. 17.

${ }^{3}$ Diren Çakmak, "Osmanlı Telif Hukuku ile İlgili Mevzuat”, Selçuk Üniversitesi Türkiyat Araştırmaları Dergisi, Say1: 21, Konya 2007, s. 196.

${ }^{4}$ Çakmak, agm, s. 229.
} 
yüz Osmanlı altınına kadar nakdi ceza alınacağı, faillerinin de bir haftadan iki aya kadar hapis olunacağı ifade edilmiştir. ${ }^{5}$

1910 tarihli Telif Kanunu'na rağmen gazeteler birbirlerinden kaynak göstermeden haber almaya devam etmişlerdir. Ancak birçok gazete bu durumdan şikâyet etmemiş ise de zaman zaman bu işten rahatsız olan gazeteler de olmuştur. Osmanlı dönemi gazetelerinde yapılan tarama neticesinde bu konuya dair üç hadise tespit edilmiştir. Bunların birincisi 1910 yılında Tanin ile Sabah arasında, ikincisi yine 1910 yılında İkdam ile yine Sabah arasında, üçüncüsü ise 1921 yılında Vakit ile Peyam-ı Sabah arasında yaşanmıştır. Bu üç hadise gazeteler arasında yapılan bir tartışma ve teşhir şeklinde kalmış, hukuki bir süreç yaşanmamıştır. İntihale dair ilk tartışma, Telif Kanunu'nun yürürlüğe girmesinden yaklaşık dört ay sonra Sabah'ın kaynak göstermeden Tanin'den haber almasıyla yaşanmıştır.

\section{1- Sabah'ın Tanin'den “Haber Aşırması” Meselesi}

Sabah'ın Tanin'den kaynak göstermeden haber almasına dair iddia 17 Eylül 1910 tarihli Tanin gazetesinde gündeme getirilmiştir. Miladi 17 Eylül 1910 tarihi Hicri Ramazan ayının 12'sine denk gelmektedir. Belirtilen tarihteki Tanin'de Ramazan gecelerinde okuyucuların çoğunun sokaklarda olmasından dolayı gazetenin beşte altıda dağıtıldığı, ancak bu erken basımdan yararlanarak Sabah gazetesinin 16 Eylül tarihli Tanin'in haberlerinden üç tanesini aldığ 1 ifade edilmiştir. Tanin'in belirttiği üç yazı "Reji Komisyonunun Maliye'de İn'ikadı", "Maliye Nazırının Darphaneyi Ziyareti" ve "Dâhiliye Nazırının İngiltere Dâhiliye Nazırına Ziyafetine Dair" başlıklı yazılardı. ${ }^{6}$

Tanin, Telif Kanunu yürürlüğe girmeden önce bu şekilde haber alan gazetelerin "yalnız vicdan-1 umumi-i millet karşısında" kaldıklarını, ancak kanunun çıkmasından sonra işin değiştiği, Sabah'ın Tanin'den aldığı haberlerin kaynağını göstermediği için Telif Kanunu'nun 32. maddesine göre yüz liraya ceza ödeyeceği gibi en faillerinin az bir hafta hapse mahkûm olacağı kaydedilmiştir. Ancak Tanin, arkadaşlık hukuku adına "teşhiri kâfi”" görerek bir şartla dava açmayacaklarını açıklamıştır. Bu şart da Telif Yasasına göre ödenecek cezanın üst sınırı olan yüz Osmanlı lirasının Donanma Cemiyeti'ne bağışlanmasıydı. Tanin, Sabah'ın Donanma Cemiyeti'ne bir hafta içinde yüz Osmanlı lirasını ödememesi durumunda dava açmaya mecbur kalacaklarını, dava açıldıktan sonra da kendileri vazgeçse bile müddeî-i umuminin takibe mecbur olacağını, bu nedenle iş işten geçmeden Sabah'ın gerekli yardımı yapmasını tavsiye etmiştir. ${ }^{7}$

Tanin, bununla da yetinmek istememiş ve Sabah'ı haber çalarken suçüstü yakalamak için büyük bir oyuna girişmiştir. Bu oyun, Tanin'de bazı yanlış havadisler vererek bunları Sabah'ın almasını temin etmekti. Ancak Tanin muharrirleri, belirttiklerine göre, sonradan düzeltme imkânı olsa bile bir günlük yanlış haber vermeyi tasvip etmemişler ve çözüm olarak Tanin'i, biri yanlış haberleri içeren, diğeri normal baskı olarak iki defa basmayı düşünmüşlerdir. Neticede uydurma haberleri içeren 8 nüsha Tanin basılmıştır.

Sira, bu uydurma haberli gazetelerden birinin Sabah'ın eline ulaştırılmasına gelmiştir. Gazete dağıtıcıları gündüz gazetelerinden bir demet alarak üzerlerine birer tane uydurma haberleri ihtiva eden Tanin koymuşlar. Dağıtıcılar Sabah matbaasının

\footnotetext{
${ }^{5}$ Düstur, 2. Tertip, II, Dersaadet 1330, 278.

${ }^{6}$ Adı geçen harfi harfine aynı üç yazı için bkz. Tanin, 3 Eylül 1326; Sabah, 3 Eylül 1326, s. 3.

7 “Sabah Refikimiz ve Havadis Aşırması", Tanin, 735, 4 Eylül 1326, s. 1.
} 
önünden geçerken, Sabah çalışanları bir Tanin alarak incelemiş ve gazetede gözlerine ilk çarpan "Tanin'in Müstahberât-ı Hususiyesi" başlığı altındaki, "Havran'da

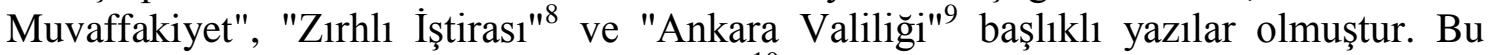
önemli haberlerin kendilerinin atlatılarak ${ }^{10}$ iktidara yakın olan Tanin'e verilmiş olduğunu $^{11}$ düşünen Sabah muharrirleri adı geçen yazıları aynen gazetelerine aktarmışlardır. Ancak Tanin'in gerçek baskısı ellerine geçince, Sabah çalışanları düştükleri durumu açık bir şekilde anlamışlardır. Zira Tanin'in esas baskısında "Tanin'in Müstahberat-1 Hususiyesi" başlıklı yazı kaldırılmış, yerine Sabah'ın Tanin'den haber çalmasını anlatan "Sabah Refikimiz ve Havadis Aşırması""12 başlıklı yazı yerleştirilmişti. Sabah çalışanları hemen harekete geçerek dağıtılan gazeteleri geri toplamaya çalışmışlarsa da satılan 300 kadar nüshaya ulaşamamışlardır. ${ }^{13}$

Olayın ertesi günü Sabah, Tanin'in haberlerini aldığını kabul etmiştir: "Her matbaada "havadis almak, havadis yazmak" namına bir hüsn-i istirkab vardır ki en

\footnotetext{
8 "Zırhlı İştirası" başlıklı uydurma yazı şöyleydi: "Devlet-i Osmaniye Amerika-yı cenubi hükümetlerinden İdiot Cumhuriyeti (Idiot aptal demektir -Tanin ) tarafindan Armstrong destgâhlarına sipariş edilen ve geçenlerde ruy-1 deryaya tenzil kılınan on dokuz bin tonilatoluk iştiraya muvaffak olmuştur. Dridnotun teçhizatı üç aya kadar hitam bulacağı cihetle nihayet dört aya kadar limanımıza gelecektir." Tanin, 5 Eylül 1326, s. 2.

9 Ankara Valiliği" başlıklı uydurma yazı şöyleydi: "Ankara valiliğine Şura-yı Devlet-i Maliye dairesi reisi Nuri Beyefendinin tayini takarrür ederek keyfiyet arz-1 atabe-i ulya kılınmıştır”, Tanin, 5 Eylül 1326, s. 2.

${ }^{10}$ Osmanlı döneminde gazeteciler birbirlerinden haber atlatabilmek için ilginç yollara başvurmuşlardır. Örneğin Halil Lütfi Dördüncü'nün anlattığına göre Mütareke yıllarında Ali Naci Karacan Anadolu'dan haber getiren bir tayfayı odaya kilitleyerek aynı haberi Tercüman'ın almasını engellemiştir. Halil Lütfi Dördüncü olayı şöyle anlatmaktadır: "Birinci Cihan Savaşı bitmiş, Mütareke dönemindeyiz. İstanbul işgal altında, Anadolu harekâtından haber alınamaz bir zamandaydı. Gazete muhbirleri Marmara'dan İzmit Körfezinden ve Karadeniz'den gelen vapur, motor, taka vesair deniz vasıtalarını kollayarak haber ve havadis almaya çalışıyorlardı. Bizim için bu deniz vasıtalarının geldiğini veya geleceğini öğrenmek ve kaptan, tayfa veya yolcuların getirdikleri resmi tebliğ veya Hakimiyet-i Milliye gazetesini ve hatta Anadolu'nun muhtelif vilayetlerinde çıkan gazetelerden bulduklarımızı edinmek birinci meşgale idi. Bunun için de Sirkeci'de tramvayın saptığı sokağın başında altında birahane, üstünde kahvehane olan yerde muhbirler toplanır, oturur ve oradan Kızkulesi'ni gözlerdik. Kızkulesi önünde İngilizlerin karakol gemisi durur, Marmara'dan İzmit Körfezinden Karadeniz'den gelen deniz vasıtalarını kontrol ederdi. Biz kontrolden çıkan gemilere derhal sandalla gider, heber, havadis ister ve varsa resmi tebliğ ve Anadolu gazetelerini alırdık. Bazı tayfalar bunları para karşılığ 1 satarlar ve bu suretle bir de havadis ticareti yaparlardı. Gazete muhbirleri bu parayı aramızda taksim ederek öderdik. Bir gün Akşam gazetesinin muhbiri rahmetli Sadettin ile Tercüman'ın muhbiri Talat Hemşehri on liraya pazarlık ettikleri bir resmi tebliğin parasını vermek için takanın bu tayfasını Akşam matbaasına götürdüler. Ali Naci Karacan parayı verdi fakat adamı odaya kilitledi. Çünkü haberi rekabet dolayısıyla Tercüman'ın koymasını istemiyordu. Zavallı Talat söylene söylene ayrılmaya mecbur oldu", Orhan Koloğlu, Osmanlı Döneminde Basın Teknikleri ve Araçları, İstanbul 2010, s. 203.

${ }^{11}$ Hüseyin Cahit, yıllar sonra yazdığı hatıralarında devlet dairelerindeki İttihatçı memurlar sayesinde diğer gazetelerin ulaşamadığı birçok belge ve habere ulaştığını itiraf etmiştir: “...Gazetecilik bakımından da bu cidden harika denilecek bir mazhariyetti. Rumeli'de vali ve kumandanlar tarafından gelen şifreli mahrem telgraflar Tanin'de herkesin gözü önüne konuyordu. Resmî dairelerin hemen hepsinde, İttihat ve Terakki ve vatan davasına büyük bir feragat ve mahviyet içinde hizmet etmeyi adeta dinî ve kutsi bir vazife bilmiş halis, fedakâr İttihatçılar istikballerini feda etmeyi göze alarak bu vesikaları Tanin'e getiriyorlard1. Geceleri bazen, gazetenin telefonu çalardı. Bir ses: Beyefendi, derdi, Noradunkyan (Hariciye Nazırı) saray ile konuşuyor, dinlemek ister misiniz? Yüzlerini görmediğim, isimlerini bilmediğim bu İttihatçı kardeşler müşterek vatan mücadelesinde kendilerinin de ufak bir hizmetleri olmasını en büyük vazife biliyorlardı...”. Bkz. Hüseyin Cahit Yalçın, "Meşrutiyet Hatıraları 1908-1918”, Fikir Hareketleri, Say1: 177, 13 Mart 1937, s. 325-326.

12 "Sabah Refikimiz ve Havadis Aşırması", Tanin, 735, 4 Eylül 1326, s. 1.

13 “Sabah'ın Başına Gelenler-Yalancının Mumu Yatsıya Kadar Yanar”, Tanin, 736, 5 Eylül 1326, s. 1-2.
} 
lakayt muharririnden en küçük mürettibine varıncaya kadar cümlesi bu hissin malulüdür. İşte bizim muhabirlerden biri de bu hissin bahşettiği buhrana kapılarak Tanin refikimizin Ramazan-1 Şerif münasebetiyle geceleyin çıkardığı nüshalardan birinden kendisince gayet mühim gördüğü 'Reji Komisyonunun Maliyede İnikadı', 'Maliye Nazırının Darphaneyi Ziyareti', 'Dâhiliye Nazırının İngiltere Dâhiliye Nezaretine Ziyafet Verdiği' fikralarını almış, mürettiphaneye verip dizdirmiş”.

Sabah, muhabirlerinin bunu yapmakla Paris'te çıkan Voleur gazetesinin başlığı olan Jeprend mon bien ou le trouvei" yani "Malımı bulduğum yerde alırım" fetvasınca okuyucularına haber yetiştirmek için vazifesinin ifasında bir "işgüzarlık ibrazına" çalıştığını da eklemiştir.

Sabah, daha önce aldıkları üç haberin telif haklarının kendilerinde olduğu gerekçesiyle Tanin'in dava açacağını yazdığını kaydettikten sonra, Tanin'in dava açmaya hakkı olduğunu belirtmiştir. Bununla birlikte Sabah 'ta, Tanin'in dava açmamak için Donanma Cemiyetine yüz lira verilmesini şart koşmasını doğru bulmadıkları ifade edilmiştir: "... bu defa nasılsa unutmayarak yazmış olduğu "hukuk-1 refakat" namına bizden bir haftaya kadar Donanma Cemiyeti'ne yüz lira itasını öne sürmek caiz olamaz. Çünkü iane rıza-yı vicdani ile verilir. Mahkûmiyet ancak huzur-1 kanunda tefhim edilir. Sabah bugüne kadar hiçbir ianeye iktidarı dâhilinde iştirakten kaçınmamış ve bu gibi emr-i hayırda rüfekasına her vakit tefevvuk etmiştir. Donanma-yı Osmani ianesine Sabah'ın iştiraki Tanin'in dediği derecede değil, belki daha mühim olacaktır. Fakat bunu Sabah istediği vakit ve surette verecektir. Hiçbir vakit ceza-yı nakdi suretiyle değil”.

Sabah, haber ajanslarından alınan haberlerin de aynı metinlerle aktarılabileceğine dikkat çektikten sonra, bunun yanında telgrafların da kaynağını yani ajansların ismini yazmaya kanunen mecburiyet olup olmadığını sormuş ve daha sonra "Refikimiz bu kaideye acaba diğer gazetelerden fazla dikkat ediyor mu?" diye devam etmiştir.

Daha sonra Sabah'ta, Tanin'in kendilerine bir komedya oynamak istediği belirtildikten sonra özel olarak uyarılmaları durumunda buna önlem alacakları, yapılan işin ise arkadaşlığa sığmadığı ifade edilmiştir: "Biraz yukarda refikimizin bu vesile ile zikrettiği "hukuk-1 refakat" tabiri hakkında "nasılsa" kaydını derç eyleyiş̧imize taaccüp etmeyin. Çünkü Tanin dün Sabah'a bir komedya oynamak istemiştir.

Muhabirimizin kadimi bir teamül sevkiyle yaptığı işgüzarlığ biraz evvel yazdık. Tanin bunun tekrar vukuuna ihtimal vererek evvelki gece neşredeceği nüshasını iki türlü basmıştır. Bu iki ayrı nüshadan biri sırf Sabah'a mahsus olup bunda Tanin'in 'Müstehberat-1 Hususiyesi' serlevhası altına atideki 'uydurma dört fikrayı derç ederek ve bir müvezzi koltuğuna vererek matbaamızın önünde sattırmıştır...

İşte Tanin bizi bu suretle bir girive-i gaflete düşürmek istemiş ve filhakika muhabirimiz bu havadisten bir ikisini almış ise de biraz sonra ahaliye satılmak için tab olunan Tanin nüshalarından birinin eline geçmesi üzerine ayılarak işte su-i niyyet olduğunu anlamış ve gazetemizden ancak birkaç nüsha basılmış olduğu halde o fikraları çıkarmıştır.

Eğer refikimiz böyle bir hal vuku bulduğunu bize hususi surette ihtar etseydi zaten gazetenin revacını bu gibi şeylerde aramadığımız cihetle ihtar-1 hayırhahanesinin telakki edileceği şüphesiz idi. İşte bu kadar ehemmiyet verilmesine nazaran uhuvvet-i refakatkaranenin nerelerde kaldığını anlayamıyoruz. 
$\mathrm{Bu}$ hadisenin kariini bundan ziyade işgal edecek bir mahiyeti yoktur. Eğer refikimiz ikame-i dava ederse mahkeme elbette işi takdir eder ve bize bir mesuliyet terettüp ettiği halde maal-memnuniye kabul eyleriz, bu suretle Hakk-1 Telif Kanunu'nun ismi de bir kere olsun mahkemelerde zikredilmiş bulunur. Fakat bizimle münasebatında samimiyet mevcut olduğunu zan ettiğimiz bir refikimizin bizi aldatmak için bilhassa birkaç nüsha-i fevkalade (!) tab ettirip matbaamız önüne kadar göndermeye zahmet etmesi matbuat-1 Osmaniye tarihçesinde garaib-i şuûndan olarak ilelebed payidar olur". 14

Sabah'ın aynı nüshasında Tanin'in de kaynak göstermeden başka gazetelerden haber aldığı ispatlanmaya çalışılmıştır. Sabah, 11 Eylül 1910 tarihli Tercüman-ı Hakikat gazetesinde yer alan "Şüpheli Ziyaret”" başlıklı haberin 12 Eylül 1910 tarihli Tanin'de "beyan edip" yerine "söyleyerek" diye aktarılarak diğer kısmının aynen alındığını yazmış her iki gazetenin haber metinlerini de arka arkaya eklemiştir. ${ }^{15}$

Sabah'ın Tanin'den kaynak göstermeden haber aldığını itiraf etmesine Tanin'in tepkisi şöyle olmuştur: "Nasılsa şeytana uyarak gazetemizden havadis aşıran Sabah refikimiz cürm-i meşhut halinde yakalandığı için bittabi dün mahzun mahzun itiraf-i cürm etmekten yapacak başka bir şey görememiş. Meğer Sabah refikimizin -yahut Sabah muhabirinin- bu işgüzarlığı teamül-i kadim sevkine mebniymiş! İşte bundan dolayı vaktiyle Paris'te çıkan Hayırsız nam-1 gazetenin dediği gibi "malımı bulduğum yerde alırım" fetvasına tabiiyet suretiyle bir işgüzarlık ibrazına çalışmış, bütün mesele bundan ibaretmiş, herhalde bir teamül-i kadime teb'an kendi hakkı olmayan şeylere el uzatan bir muhbir her kim ise bir gün yine böyle bir teamül-i kadime mağlup olarak Mihran Efendi'nin cebine de elini sokuverirse o zaman refikimizin halini görürüz!.

Donanma Cemiyeti'ne yüz lira vermek bahsine gelince, refikimiz yarı dargın bir çehre ile kendisi Donanma Cemiyeti'ne bundan çok vereceğini fakat böyle cebren ve kerhen vermeyeceğini söylüyor. Ziyan yok, onlar böyle bir muavenette bulunsunlar, biz cebr ve kerh sözünü yahut imasını geri alırız. Kendisine rica ediyoruz, hamiyet ve mürüvvetine itimat eyleriz. İşte artık ortada izzet-i nefis meselesi de kalmadı. Biz yüz rica ediyoruz, refikimiz iki yüz iane etsin, bizi mahcup bıraksın, kendisinin kavlince matbuat-1 Osmaniye tarihçesinde ilelebet garaib-i şuundan olarak payidar kalacak bu vak'a da böyle latif bir surette kapansın". ${ }^{16}$

Tanin'in Sabah'a oynadığı oyun La Türki'nin de sıkıntı yaşamasına neden olmuştur. O zamanlarda La Türki ile Tanin haber alışverişi yapmaktaymış. La Türki önemli bir haber olursa Tanin'e yollarmış, bunun karşılığında Tanin de baskıya girmeden önce provalarını La Türki'ye gönderirmiş. Tanin'in Sabah için hazırladığı provalar yanlışlıkla $L a$ Türki'ye gitmiş ve Tanin çalışanları bunların basılmasını önlemek için bir hayli gayret sarf etmişlerdir. Tanin bu gayretlerini şöyle anlatmaktadır:

"Tanin, Sabah refikine o meşhur âlem-i matbuatta bir garibe-i tarihiye olarak kaydedileceğini dünkü nüshasında refikimizin de itiraf ettiği büyük azizliği yapmağa karar vermiş, tulca birbirine müsavi iki fikra yazmış, makinede değiştirilmek üzere hazırlamıştı. Bu iki fikradan birisinin "Tanin'in Müstahberat-1 Hususiyesi” namı altındaki Sabah refikimizin matbaasına hediye edilecek nüshaya mahsus saçmalar,

\footnotetext{
14 “Biz ve Tanin Refikimiz”, Sabah, 5 Eylül 1326, s. 2.

15 “Sabah'ın Başına Gelenler-Ne Gelmiş?", Sabah, 6 Eylül 1326, s. 2.

16 “Sabah'ın Başına Gelenler”, Tanin, 737, 6 Eylül 1336, s. 1.
} 
diğerinin de yine Sabah refikimizin havadis aşırmasına itiraz için yazılmış olan fikra olduğunu söylemeğe lüzum yoktur değil mi?

$\mathrm{Bu}$ yazılar hazırlandıktan sonra mürettip hatalarının tashihi için birer provalar çıkar, musahhihlere gider. Diğer taraftan da öteden beri Tanin ile La Türki arasında bir usul vardır, La Türki refikimiz mühim bir havadis bulursa bize yollar, biz de buna mukabil gazete basılmadan evvel provalarımızı ona yollarız, o da mühim havadis ve makaleleri tercüme eder. Binaenaleyh Fransizca kariler, bilhassa muhabirler, ecnebiler günü gününe Tanin'in kendilerine lazım olan kısımlarını okumuş olurlar.

İşte evvelki akşam da bu provalar hazırlanır, La Türki'den gönderilen adam, hepsini alır götürür. Tanin'in Müstahberat-1 Hususiyesi de bittabi bunların içinde. Provalar, gider ve hiç kimsenin aklına gelmez ki La Türki'de bu Müstahberat-1 Hususiyenin yalan yanlış tercüme edilip girmesi ihtimali var. Vakıa her ne kadar “Afrika'da Eskimolar Şimendiferi, Amerika'da İdiyu! Hükümeti gibi insanın inanamayacağı şeylerin nazar-1 dikkati celp etmek ihtimali var ise de provalar daima tashih edilmeksizin gönderildiği cihetle bu havadisleri orada okuyacak olan mütercim bunları mürettip sehivlerine isnat edecek ve oralarını sudan geçmek suretiyle tercümeden çekinmeyecekti.

Şimdi işin gülünç, daha doğrusu acıklı cihetini anladınız, değil mi? Zavallı La Türki Sabah refikimize kurduğumuz tuzağa düşüyor, hem de ne düşmek! Bereket versin, Sabah'a kurulan tuzağın tertibatına ilk sahifedeki yazının tebdiline nezarete memur olan muharririmiz birden bire mürettiphanede dolaşırken duvarda her vakit $L a$ Türki'ye gidecek provaların asılı durduğu çivinin boşalmış olduğunu fark eder ve bir anda işin nerelere vardığını görür. Şimdi ne yapsın? Saat beş buçuğa geliyor, provalar gideli belki de bir buçuk saat oldu, belki de La Türki' de kimse yok. Zavallı gidiyor!

Hemen kâğıdı, kalemi alır, işi birkaç kelime ile hülasa eder, yollayacak. O esnada matbuatın kapısının önünde müvezziler hazırlanmışlar, Tanin'i bekliyorlar, gece satışına çıkacaklar. Bunlardan açıkgözlüce birisini çağırır, büyükçe bir bahşiş, "haydi!” der. Müvezzi o kadar süratle gider gelir ki mektubun cevabı üç çar-yekte makinenin başında muharririmizin eline tutuşturulur. $\mathrm{O}$ da geniş bir nefes alır.

Bununla burada bitiyor mu? Hayır. Daha başka bir vak'a var: Meğer ecnebi muhabirler Tanin Müstahberat-1 Hususiyesinin gece La Türki' ye geldiklerini bildikleri cihetle alafranga onda, on birde oraya uğruyorlar, malumat alıyorlar. Mensup oldukları gazete veya ajanslara süratle telgraf çekiyorlarmış. $\mathrm{O}$ akşam muhabirlerden bir zat gelir, Tanin'in Müstahberat-1 Hususiyesini okur, hakikaten pek mühim havadisler olduğunu görerek hemen gider, telgrafını çeker ve tesadüfe bakınız ki La Türki'ye giden mektubumuz muhabirden sonra vasıl olur, telgrafın önüne geçmek kabil olmaz, mektubumuzu alan La Türki sermuharriri hayretler içinde, mademki bu havadisler yalandı, niçin böyle basıldı? diye düşünürken ikinci bir muhabir daha gelir, ona vakayı hikâye ederek, her ikisi de hayretler içinde kalır. Bu ikinci muhabir Ajans-1 Havas'ın İstanbul muhabir-i mahsusudur.

... İşte La Türki böyle bir Nabi Bey gürültüsü geçirdikten sonra nihayet akşam da böyle tehlike atlattı, geçmiş olsun. Dua edelim ki bir daha tekrar etmesin!". ${ }^{17}$

17 “La Türki’ye Geçmiş Olsun”, Tanin, 737, 6 Eylül 1326, s. 1. 
Konu bu şekilde kapandıktan sonra 27 Eylül 1910 tarihinde Tercüman-ı Hakikat, Sabah'ın Donanma Cemiyeti'ne yüz lira verip vermediğini, vermemiş ise dava açılıp açılmadığını sormuştur. ${ }^{18}$ Tanin ertesi günü buna cevabında Sabah'ın Donanma Cemiyeti'ne yüz lira verdiğini duymadıklarını, bununla birlikte dava açmaktan da vazgeçtiklerini açıklamıştır: "Tercüman-ı Hakikat refikimiz Sabah gazetesinin donanma ianesi için yüz lirayı verip vermediğini, vermemiş ise bizim ikame-i dava edip etmediğimizi soruyor. Sabah yüz lira vermiş olsaydı elbette duyardık. Bize gelince, biz ikame-i davadan vazgeçtik. Çünkü Mihran Efendi'nin hapse girdiğini görmek istemeyiz. Maksadımız kendine düşmanlık etmek değildir. Diğer taraftan, Mihran Efendi kendi haline bırakılırsa yüz değil, daha ziyade lira vereceğini vadetmiş olduğundan elbette umum-1 âleme karşı verdiği bu sözü tutacağı mülahazasına mebni 1srara lüzum görmedik. ${ }^{19}$

\section{2- Sabah'ın İkdam'dan “Haber Aşırması” Meselesi}

Tanin ile Sabah arasındaki hadiseden dört ay sonra benzer bir olay İkdam ile yine Sabah arasında yaşanmıştır. ${ }^{20}$ Haberlerinin kaynak gösterilmeden Sabah tarafından alındığını fark eden İkdam, "Mühim Bir Sirkat" başlıklı uydurma bir haberi Sabah'ın almasını sağlamıştır. Sabah'ın aldığı uydurma haber şöyledir: "Beyoğlu'nda Sırmakeş Sokağı'nda Rusya tebaasından Madam Lili'nin apartmanına evvelki gece sârik duhulüyle ikinci katta bulunan kasayı kırarak derununda bulunan üç bin lira ile birçok âsâr-1 atika ile ve bin lira kıymetinde gerdanlık sirkat olunmuştur. Sirkat-i mezkurenin mütecasiri olmak üzere zabıtaca Kollar Yukarı Kumpanyasından şüphe edilmektedir”. ${ }^{21}$

Bu uydurma haberin Sabah sütunlarına nasıl geçtiği Tasvir-i Efkâr'da detaylı olarak anlatılmıştır: "Tanin'in bu sâriki geçende cürm-i meşhud halinde yakalamış olması intibah için kifayet etmiştir sanıyorduk. Meğer huy değişmezmiş. Bu hakikat nazarımızda bir daha tecelli etti" diyerek Sabah'1 eleştiren Tasvir-i Efkâr, Sabah'ın nasıl oyuna getirildiğini şöyle anlatmıştır:

"Sabah havadis çalmak merakını o kadar ileri götürmüş ki matbaalardaki memurin ve müstahdemin meyanında bu rolü bihakkın oynayacak kimseler de tedarik etmiş. Bunlar matbaalarda çalışırken bir taraftan da havadis getiren muhbirlerin yazılarına dikkat ederlermiş. Muhbirlerden biri müsveddelerini matbaada bir daha nazar-1 dikkatten geçirdikten sonra tekrar tesvid ve evvelki müsveddeleri buruşturup atmak itiyadında bulunduğu için Sabah'ın memurinin yahut meclubunun atılan müsveddeleri toplayarak bir suretle $S a b a h$ 'a yetiştirdiği hissedilir.

\footnotetext{
18 “Acaba Yüz Lira Ne Oldu?”, Tercüman-ı Hakikat, 10592, 14 Eylül 1326, s. 2.

19 “Sabah'ın Yüz Lirası", Tanin, 746, 15 Eylül 1326, s. 3.

${ }^{20}$ Haber "çalma" hadiselerinde genelde Sabah'ın adının öne çıkmasında sahibi Mihran Efendi'nin tutumu önemli rol oynamış olabilir. Zira Mihran Efendi, diğer gazetelerde olan bir haberi Sabah'ta göremediği zaman çalışanlarına şiddetli tepki göstermiştir. Bu konuya dair Hüseyin Cahit Yalçın şunları yazmaktadır: "Mihran da seyrek rastlanır tiplerdendi. Hemen hemen okuma yazması yok denilecek düzeyde bilgisiz olduğu halde her gün hem kendi gazetesini, hem İkdam'1 alabildiğine dikkatle okurdu. İkdam'da gördüğü bir haberi Sabah'ta bulamazsa bu onun için büyük bir üzüntü olurdu. Aynı zamanda basımevinde de büyük bir olay doğmuş olurdu. Asık yüzüyle yazı işlerine ayrılmış dar bölmenin içine girer, içine çeker, "çalışmıyoruz, dikkat ve özen göstermiyoruz; işi böyle yürütemeyiz" öndeyişiyle yakınmaya başlar, haberin neden ötürü Sabah'a geçmediğini araştırırdı”, Bkz. Hüseyin Cahit Yalçın, Edebiyat Anılarl, İstanbul 1975, s. 101.

${ }^{21}$ İkdam'ın Sabah'a kurduğu tuzağa sadece Sabah değil Yeni Gazete ve Siyaset gazeteleri de düşmüştür. $\mathrm{Bu}$ durum da kanuna rağmen birçok gazetenin kaynak göstermeden birbirinden haber almaya devam ettiklerini göstermektedir.
} 
Fakat bu her vakit olmaz a şüphesiz! Kurnazlığa kurnazlıkla mukabele edilir. Sârikini, sârik say u gayretini keşfeden muhbir de kendince bir plan tasavvur eder.

Miadında matbaaya gelir vaz-u tavr-1 kadimi vechile imla-yı havadise ve âhiz! yahut sârik havadisde kendince icad edildiği vesilelerle anın etrafinda dolaşmaya başlar.

İşte kurnazlığın müsabakası, ruhu burada!

Meğer yazacağı satırların hemen Sabah'a uçacağına kani olan muhbir hakikataşina, Sabah'a bir ikinci oyunu tasmim ile tasnî-i havadise başlamış akıl ve hayale ne gelmişse yazmış, kemafissabık son müsveddesini bir köşeye atmış. Nihayet Sabah'ın iğtinam eylediğini zan ile hemen sütun-1 vasiine naklettiği o kâzib havadis vücuda gelmiştir. Zavallı Sabah!"22

Konu daha önce Sabah'1 oyuna getiren Tanin'de de yer almıştır. Tanin "Mühim Bir Sirkat" başlıklı uydurma haberi aktardıktan sonra şöyle devam etmiştir: "Vakıa bir sirkat icra edilmişse de madam bilmem kimin kasasından değil, Ikdam'ın havadisleri arasından vukua gelmiştir. Çalanlar da acaba Kollar Yukarı! Kumpanyasından mı? Bu havadise yalnız bir fikra ilave etmek lazım: $O$ da sâriklerin cürm-i meşhut halinde yakayı ele vermiş olmalarıdır.

Zavallı Sabah! demek istiyoruz. Fakat kendi düşen ağlamaz. Onun için zavallı Sabah karileri! demeği daha münasip buluyoruz. Çünkü bundan sonra Sabah'ta gördükleri bir havadisin doğruluğuna neyle kani olacaklar?". 23

$\mathrm{Bu}$ arada haberin uydurma olduğunu bilmeyen Emniyet-i Umumiye Müdürlüğü resmi bir tekzip yayınlamıştır: "Yeni Gazete ve Sabah ve Siyaset gazetelerinin bugünkü nüshalarında Beyoğlu'nda Sırmakeş Sokağı'nda Rusya tebaasından Madam Lili'nin apartmanına evvelki gece sârik duhul ederek ikinci katta mevzu kasayı kırıp üç bin lira ile birtakım celiyyatı sirkat ettikleri ve zabıtanın Kollar Yukarı Kumpanyasından şüphe eylediği yolunda derç edilen havadis külliyen bî-asıl ve esas olup Sırmakeş Sokağı'nda Madam Lili namında bir kimse de mevcut olmadığı ve Kollar Yukarı namıla bir kumpanyanın vücudu ve bu gibi eşhastan zabıtanın şüphe etmesi de katiyen hilaf-i hakikat ve aracifden ibaret bulunduğu cihetle tekzib-i keyfiyete mübâderet olunur". ${ }^{24}$

İkinci defa oyuna gelen Sabah, "Acaba terakkiyat-1 asriyeden olarak gazetecilik mesleğine "aldatma oyunu" itlak olunur bir hüner-i nev-zuhur idhal edilmiş olduğunu ve bunun tecrübesi gazetemiz muhabirlerinden biri hakkında tatbik edildiğini dün çıkan refiklerimizde okuduğumuz bir ihtar-1 hayırhahane bize tebşir etti" diyerek İkdam'a tepki göstermiş̧tir. Ayrıca aynı oyuna Yeni Gazete ve Siyaset gazeteleri de gelmesine rağmen sadece Sabah'ın gündeme getirilmesi eleştirilmiştir.

Sabah, hadisenin haberi gazeteye getiren muhabirden kaynaklandığını, bu muhabiri işten çıkarabileceklerini, ancak "Muhabir hakkında -mahza iğfal edenlere bir gazap-1 vicdani vermek için-“" böyle bir tedbire başvurmadıklarını yazmıştır. Daha sonra Sabah yazıyı, "Biz kendi işimizle meşgul olduğumuzdan kimseyi aldatmak teşebbüsünde bulunmadık ve bulunmayacağız. Başkaları arzu ederlerse "aldatma oyununa" devam edebilir" diyerek bitirmiştir:

\footnotetext{
22 "Sabah Yine Atladı", Tasvir-i Efkâr, 476, 6 Kanun-1 sani 1326, 2.

23 "Yeni Bir Komedya", Tanin, 854, 6 Kanun-1 sani 1326, s. 1-2.

${ }^{24}$ Yeni İkdam, 6 Kanun-1 sani 1326, s. 5.
} 
"Diğer rüfekamız gibi Sabah'ın da muhabirleri vardır; Fakat erbab-1 vukuf bilir ki Sabah'1n muhabirlerinin adedi biraz fazladır. İhtiyar olunan fedakârlık da fazla bir yekûn tutar. Bunu tefahür için değil, gayr-i meşru bir tedbirle celb-i malumata bir sebep-i makul olmadığını anlatmak için yazıyoruz.

Bizim muhabirimizin nerelerden ve ne suretle malumat aldıklarını murakabe etmeyiz. Böyle bir murakabe hadd-i zatında imkân haricindedir. Muhabir olan zat vazifesini ifa eder; eğer fena ifa ederse matbaa onunla alakasını keser; ifa ederse vazifesine devam eder. Muhabirliğin hüsn-i ifa edilip edilmediğini vukuat gösterir.

Biz muhabirlerden hiç birine falan vasıta ile falan yerden malumat alınız diye talimat vermedik. Bunun zıddını kimse iddia edemez.

Gazetelerin muhabirleri hem meslek ve refiktirler; eğer isterlerse yekdiğerini her gün iğfal edebilirler. Fakat meslektaşlık uhuvvetinin buna mani olması lazım gelir.

Muhabirlerimizden birine diğer bir muhabir bir yalan malumat vermiş; o malumat gece zevali saat onda matbaaya getirilmiş. Şimdi bunun "aldatma oyunu" silsilesine mensup olduğunu beyan ediyorlar. $\mathrm{Bu}$ ihtarları üzerine havadisi matbaaya getiren muhabiri idaremizden ihraç etmek mümkün idi. Muhabir hakkında -mahza iğfal edenlere bir gazab-1 vicdani vermek için- böyle bir tedbir ittihaz etmedik. Bu hareketimiz karilerimizce takdir edilir zannederiz.

Biz kendi işimizle meşgul olduğumuzdan kimseyi aldatmak teşebbüsünde bulunmadık ve bulunmayacağız. Başkaları arzu ederlerse "aldatma oyununa" devam edebilir". ${ }^{25}$

\section{3- Vakit'in Telgrafını Peyam-ı Sabah'ın Çaldığı İddiası}

4 Aralık 1921 tarihli Vakit gazetesinde, İcra Vekillerinin sorumlulukları hakkında hazırlanan kanun layihasının 1 Aralık 1921 tarihinde Büyük Millet Meclisi'nde müzakeresi esnasında Mustafa Kemal Paşa tarafından yapılan konuşmaya ${ }^{26}$ dair hususi telgraflarının Peyam-ı Sabah tarafından "çalınarak" yayınlandığı iddia edilmiştir:

"İcra Vekillerinin vazife-i mesuliyeti hakkında tanzim edilen layiha-i kanuniyenin Büyük Millet Meclisi'nde müzakeresi esnasında Meclis Reisi Mustafa Kemal Paşa Hazretleri tarafindan irad edilen nutka dair Ankara muhabirimizin çektiği telgrafname dünkü nüshamızda münderiçtir. Bu telgrafname Ankara muhabirimiz tarafindan çekildiği ve münhasıran Vakit'e ait olduğu halde dünkü Peyam-l Sabah'ta intişar etmiştir. Peyam-ı Sabah bu telgrafnameyi Anadolu Ajansı'na ve şehrimize gelen malumat-1 resmiyeye atfen derç etmekte ise de Büyük Millet Meclisi'nin bu husustaki müzakeratına dair henüz şehrimize Anadolu Ajansı tarafından hiç bir tebliğ varit olmadığ gibi resmi malumat da gelmemiştir ve şekl-i resmide malumat gelmesinin emsali de yoktur. Binaenaleyh Peyam-ı Sabah'ın Vakit'e ait olup Vakit muharrirleri tarafından tevsi edilmiş olan, hatta Peyam-ı Sabah sütunlarında virgüllerine, noktalarına kadar aynı tarzda intişar eden bu telgrafnameyi gayr-i meşru vesaitle ele geçirdiği anlaşılmıştır. Bu vesait hakkında elimizde kâfi derecede delail mevcut olmakla beraber şimdilik bundan bahse lüzum görmüyoruz. Yalnız Vakit'in karilerine borçlu olduğu hizmeti ifa için ihtiyar ettiği bütün fedakârlıklardan meslek namına şeyn olan sefil

\footnotetext{
25 “Aldatma Oyunu Hakkında”, Sabah, 7661, 7 Kanun-1 sani 1326, s. 1-2.

${ }^{26}$ Mustafa Kemal Paşa'nın konuşması için bkz. TBMM Zabıt Ceridesi, 23. İçtima, Cilt: 14, Ankara 1958, s. 411-432.
} 
vesaite müracaatla nasıl istifade edildiğini ispat etmek maatteessüf bir de Vakit'in uhdesine düşen bir borç olduğuna kaniiz. Şu kadarını tasrih edelim ki Sabah'ın kullandığı gayr-i meşru vesait telgrafhanenin de matbaamızın da büsbütün haricindedir".

Sabah'ın tuttuğu bu çirkin yolun kendisinin tarik-i hassı olduğuna dair karilerimizin zaten kâfi derecede malumatları olacaktır. En evvel hatırladığımız hadise Tercüman-ı Hakikat'le Sabah arasında olmuş idi. O zamanlar Sabah'ın bu gizli macerasından bizar olan Tercüman-ı Hakikat bir gün "felisit danadan" nişanı itasına dair bir fikra tasni etmiş ve Sabah'ı cürmü meşhud halinde yakalamıştı.

Sabah'ın hayat-ı neşriyesinde uğradığı ikinci mühim bir yakalanışının kahramanı da Tanin'dir. Hususi haberlerinin Tanin'in erken, Sabah'ın gece tab'a verilmiş olmasından istifade edilerek daima Sabah'ın sütun-1 malikiyetine intikal ettiğini gören Tanin yine bir Ramazan gecesi "İdiyo Cumhuriyetinden iki sefine-i harbiye iştira edildiği" ne dair bir fikrayı ihtiva eden tek bir nüsha çıkarıp bunu Sabah'ın malum olan vasıtasıyla Sabah matbaasına nakletmiş ve bu gülünç haber Sabah sütunlarında yakayı ele vererek uzun müddet matbuat âleminde çalkalanmış durmuştu.

Bizse bugün onu kendi yolunda hiç kasd-1 taammüdümüz olmadığı halde yakalıyoruz ve Peyam-ı Sabah'ı otuz üç yaşına rağmen malum olan itiyadda ber-devam olduğunu görerek müteessir oluyor ve kendisini Vakit'e ait hususi bir telgrafi çaldırmakla itham ediyoruz.

Bir gazetenin diğer bir gazeteye ait hukuk-1 meslekiyeye bu çirkin ve devamlı tecavüzün mevki-i aleniyete konulmasından müteessir olanlar varsa onları Peyam-ı Sabah'ın bu hareketleriyle meslektaşlık sıfatını kendi kendisinden çok zaman evvel nez' etmiş olduğunu da unutmamalıdır". ${ }^{27}$

Peyam-ı Sabah'ın Vakit'e verdiği cevapta ise Vakit'in şikâyetinin bütün engellemelere rağmen Peyam-l Sabah'ın Anadolu haberlerini yayınlayabilmesinden kaynaklandığı belirtilmiş, daha sonra Peyam-ı Sabah'ın o ana kadar olduğu gibi gelecekte de önemli haberleri okuyucularına yetiştireceği ifade edilmiştir: "Vakit gazetesi dün Mustafa Kemal Paşa'nın Büyük Meclisinde heyet-i vekilenin vazife ve mesuliyetine dair irad etmiş olduğu nutku kendisiyle aynı zamanda neşredebilmiş olmamıza izhar-1 hayret ve telehhüf ediyor ve bu nutku sirf kendine mahsus addederek gazetemize bu vesile ile tecavüzde bulunuyor idi. Vakit'in bu inhisar-1 havadis yaygarası, bu hayret telehhüfü gazetecilik gavamız ve bir gazetenin en birinci vazifesi günü gününe karilerine havadis yetiştirmekten ibaret bulunduğunu bilenler nazarında tıfl-ane ve gülünç adedilmekle beraber pek tabii görülmek lazımdır.

Zira son aylar zarfinda Vakit'in de parmağı bulunduğu halde umumun malı olmak lazım gelen resmi tebliğleri ve Anadolu ajanslarını bize vermemek ve bu suretle güya karilerimizi Anadolu vekayi ve harekatından mahrum bırakmak hülyasıyla çevrilen entrikaları, kurulan dolapları akim bırakmamız ve hatta kendileri elde edemedikleri halde bir çok defalar Anadolu tebliğleri ile mühim haberlerini münhasıran bizim yazmamız Vakit'i şaşırtıyor idi. Son muvaffakiyet-i istihbariyemiz ise onu zıvanadan çıkarmış; İşte gazetemize karşı yapılan tariz ve hücumun, bütün entrikalara rağmen bizi Anadolu haberlerinden mahrum bırakamamaktan mütevellid acı bir inkisar halidir.

27 "İtham Ediyoruz", Vakit, 1431, 4 Kanun-1 evvel 1921, s. 1. 
Peyam-ı Sabah'ın bu ana kadar olduğu gibi istikbalde de mühim haberleri günü gününe karilerine yetiştirebileceğine şüphe etmesinler ve beyhude yaygaralara, inhisar-1 havadis iddialarına kalkışmasınlar".

Peyam- $\iota$ Sabah'ta daha sonra, Mustafa Kemal Paşa'nın nutkunu zamanında gazeteye yetiştiren muharririn de para ile ödüllendirildiği belirtildikten sonra, "Şurası da bilinmelidir ki bir gazetenin en birinci vazifesi nereden ve kimden olur ise olsun umumi malumatı cem ve neşretmek hususunda muvaffakiyet ibraz etmekten ibarettir. Acaba Vakit Refikimize muhabir böyle bir havadis getirmiş olsaydı ne yapardı! ..." diye sorulmuştur. $^{28}$

Peyam-ı Sabah'ta Peyam-1 Eyyam kısmındaki yazıda ise Ileri, Akşam ve Ikdam gazetelerinin tekelinde olan Anadolu haberlerinin Peyam-ı Sabah'a geçmesinin "Selanik yardakları"nı küplere bindirdiği ifade edildikten sonra bunun sebebi şöyle açıklanmıştır: "Çünkü bir zaman Makedonya'yı hemen bütün Rumeli'yi benimsediler, biz başmuharrirlikte iken İkdam'ı o iklime sokmazlar ve sokturmazlard1, o havaliden bize hiç havadis verdirmezlerdi. Himmet-i iblisaneleriyle o topraklar elimizden çıktı. Fakat va esafa, o yadigârlar bizde kaldılar, bu sefer de aynı istibdatı Anadolu'da mevki-i tatbike koydular.

Peyam- Sabah'1 o diyarda okumak bir cinayet imiş, işitiyoruz. Fakat Anadolu'dan karilerine malumat vermek bu gazete için nasıl bir kabahat teşkil eder? Anlayamiyoruz, hangi gazeteye mahsus olursa olsun herhalde müstebidane olduğu derecede haksız bir inhisara rağmen o haberleri ele geçirmek ve gazetemize derceylemek Mihran Efendi'nin hem kar-anahiliğine, hem de gayret ve meziyetine delalet eder"

Peyam-ı Sabah, Vakit'in "İtham Ediyoruz" başlığına da sert tepki göstermiştir: "İtham ediyoruz. Kimi itham ediyorsunuz? Esasen üç buçuk kişiden mürekkep bir serseri güruhu idiniz, bin türlü dolaplarla bir cemiyet-i hafiye teşkil eylediniz, bütün mukaddesatını an'anatını haraca mezada vererek bu milletin mukadderatını yed-i gasbınıza geçirdiniz, varını yoğunu havaya verdiniz, malını, mülkünü yağma eylediniz, izmihlal-i tammını elinizle hazırladınız, lakin hâlâ yakasını bırakmıyorsunuz, istiyorsunuz ki kabza-i istibdadınızda erir, giderken hakiki, en samimi evladından hiçbiri imdadına şitab etmesin, tahlisine bir çare aramasın.

... Bu devlet ve millet bu dereke-i zevale yuvarlanmış olsun, sizin için beis yok, henüz han-1 yağmaya sermaye olabilir. Bir iki vilayetimiz daha kald1, öteden beri fitratınıza hastır. Böyle fırsatlardan istifadeyi pek mükemmel bilirsiniz...

Her kabahatinizi her cinnetinizi alkışlamayanları ise havsalaya sığmaz hiyanetlerle cinayetlerle ithama kadar varınız ...

Hakikaten Peyam-ı Sabah için hâlâ ne cürettir ki lahana yapraklarının kızıl kızıl tekrim ve takdisinizde inkişaflarından, secdelerinden ibret almıyor da sizden hak ve hakikat lisanıyla bahse kalkışıyor, bu günahı haşre kadar afv olunmasa yeridir". ${ }^{29}$

Vakit ertesi günü Peyam-ı Sabah'a cevap vermiştir: "Evvelki gün Peyam-ı Sabah'1 elinde maymuncuklarıyla yakalamış "işte bütün İstanbul matbuatının emniyet ve mahremiyetini birbirine karşı bizzarure tekeffül ettikleri bir yerden mahreciyle, tarihiyle

28 "Garip Bir İtham," Peyam-l Sabah, 11508, 5 Kanun-1 evvel 1337, s. 1.

${ }^{29}$ Peyam-l Sabah, 11508, 5 Kanun-1 evvel 1337, s. 1. 
mürsiliyle hatta hemen hemen yarı yarıya kelimeleriyle Vakit'in mülk-i has ve meşruu olan bir telgrafı aşıran, çalan budur, kendisini halkın adil mahkemesi önünde itham ediyoruz!" demek istemiştik.

$\mathrm{Bu}$ itham hükmünü verirken elimizdeki deliller o kadar kuvvetli idi ki cümlelerimizi tanzim ederken hiç de ihtiyatkâr olmaya lüzum yoktu. Böyle olmakla beraber faziletin sesi bizi günah-kari yalnız bir misal-i ibret olmadan başka bir kılıkta teşhire sevk etmedi. Peyam için ve onları çıkaranlar için ağızlardan çıkarılacak bakla Raşid Bey'in maruf baklasından herhalde çok büyüktü. Biz sadece haber vermek ve itham etmekle iktifa ettik.

Dün Peyam-ı Sabah tam yavuz hırsız kıyafetinde göründü. Bir taraftan Mihran Efendi'nin sütunu, öbür taraftan Ali Kemal Bey'in ki... Gürültüye pabuç bıraktırmak için kaleme sarılmış!

Malumdur ki Peyam-ı Sabah ismi gibi ikiyüzlü bir gazetedir: Başmakalesiyle Peyam-1 Eyyamları "zorba"dan "dududan" yukarı çıkaramazken içi sütunlar "Mustafa Kemal Paşa Hazretleri", "Halide Edip Hanım, Halide Edip Hanımefendi" demek de 33 senelik gazeteciliğinin teyid ettiği bir menfaat mülahaza eder.

İşte bu iki çeşit sütunlardan Mihran Efendi’ye ait olanları dün bizi hiç üzmeden açıkça itiraf ediyorlar: "Çaldınız!" ithamına karşı "bir gazetenin en birinci vazifesi nereden ve kimden olursa olsun umumi malumatı cem ve neşretmek hususunda muvaffakiyet ibraz etmekten ibarettir" dediler.

Biz "Sabah'ta çıkan satırların bizim gazetemizdeki hususi telgrafin harfi harfine aynıdır, siz bunu çaldırdınız" demiştik. Mutad olan el çabukluklarıyla "hususi telgraf" iddiasını "nutuk" kelimesine çevirmek ve öylece işin içinden sıyrılmak istediler.

Peyam-ı Sabah bu nutku yani bizim hususi telgrafımızın aynını neşrederken bu havadisi resmi menbalarla Anadolu Ajansı'na atfediyordu. Biz bu ciheti tekzip ettik. Bunu işitmezliğe geldiler.

Nereden kimden ve -hatta biz ilave edelim- nasil ne vasita ile olursa olsun havadis cem ve neşretmekle adeta havadis çalmak ve aşırmak arasında hiç bir fark olmadığını iddia ettiler!

Be Mihran Efendi, biz bizim hususi telgrafımızı aldınız demiyoruz, çaldınız diyoruz. Çaldınız! hem öyle bir yerden çaldınız ki...

Peyam-1 Eyyam'ın muharrir-i mağşuşuna gelince: Kısaca biz çalmadık demek varken ne ağız kalabalığı yapmak külfetine katlanmış. Bermutad Selaniklilikten, inhisarcılıktan dem vurmuş vurmuş. Sabah'ın 33 senelik nüshalarını dizen kurşunlar kadar ağır sözler işitmiş bir adamın çaldınız! ithamı karşısında bu coşması gayri tabii bir hareket olmaz mi? Biz ithamımızı onların ne eski ne yeni fazahatlerinden bahsetmek için yapmadık: Kısaca hususi telgrafımızı çaldınız dedik. Bu hakkı müdafaa etmekte Peyam-1 Eyyam muharririne sani olmak elbette ne elimizden gelirdi, ne aklımizdan geçerdi. Hele bize inhisardan bahsetmenin hiç de manası yoktu. Zira bizim Ankara'daki hususi muhabirimizin telgrafları elbette bizim malımız olur, elbette bunlar üzerinde bir inhisar da iddia edebiliriz. Hukuk, kanun, teamül bütün bu hasr ve kasrı bizim lehimize temin ediyor. Fakat Sabah'ın doğrudan doğruya ve açıktan açığa Anadolu havadisi almaktan mahrum olmasının mesuliyetini kendi kötü ruhunda arayacağı yerde bize atf-1 isnad etmesi kadar biçare bir iddia var mıdır? Vakit gazetesi karilerinin gazetesidir; 
Vakit gazetesi Sabah'ın 33 senelik kapalı hayatında yapamadığını açık alnıyla ve açık alınlara has ve mevud olan bir mazhariyetle yapmış, karilerini her zaman ve herkesten evvel dünya vekayiinden haberdar etmiştir.

Vakit gazetesi elbette Peyam-ı Sabah için çalışmaz. Nasıl ki Peyam-ı Sabah da Vakit için çalışmayacaktır. Elbette her gazetenin aldığı haberler evvela kendinin saniyen karilerinin inhisarına dâhildir.

Mustafa Kemal Paşa'nın irad ettiği nutku orada herkes dinleyebilirdi. Fakat bu nutku neşretmek bu kadar fedakarlık yaparak onu kendisi için ihzar edenlere ait bir imtiyaz ve inhisardır; sırası gelmişken şurasını da hatırlatmalıyız: Garip bir tamim ile inhisarcılığından şikayet ettikleri Vakit'dir ki kendisinden başka bir gazeteye tevdii mezuniyetiyle verilmiş olan haberleri telefonla Peyam-ı Sabah'a yetiştirmişti!...

Peyam-ı Sabah ise bir başkasının bütün gazetelerin yekdiğerine karşı emniyetini tekeffül ettikleri bir yerden bizim hususi telgrafları çalıyor! Tekrar edelim, almıyor çalıyor! Bu ithamı yapan Selanikli olsun, Ankaralı olsun hepsi bizce müsavidir. Fakat Peyam-1 Eyyam muharriri ikisi arasında fark buluyorsa haber verelim ki gazetesini itham edenler Selanikli oldukları kadar kendi ihanetinin cezasını hâlâ bütün bir milletle beraber çeken bir yurdun evlatlarıdır.

Peyam-l Sabah bu hırsızlık ithamı karşısında arsızca bir tefahürde de bulunduğundan bu vesika-i sirkati kendisine yetiştiren muharririni idarece mükâfat-1 nakdiye ile taltif ettiklerini söyledikten sonra soruyor: "Acaba Vakit refikimize muhabir böyle bir havadis getirmiş olsa idi ne yapardı?" yapardi.

Ne yapardı öyle mi? Herhalde Peyam-ı Sabah'ın yaptığından başka bir şey

Öyle gece yarısına doğru bütün mürettipler değil nöbetçiler bile işini bitirip gittikten sonra bin rica ve niyaz ile dizdirilmiş ve "Landru'nun idamı" ${ }^{30}$ hakkındaki fikra çıkarılarak yerine konulmuş bu havadisi gazetede görünce bilahare bunu getiren maymuncuk muharririne üç lira mükâfat-i nakdiye verecek kadar kıymetini yüksek bulduğu bu mâl-i mesrukı -garip tesadüf!- Landru'nun yerine koymuş olan mürettibe yol veremezdi.

İlk gün -kendisini sirkate sevk ve teşvik etmeyeceği için- bu muharriri belki taltif ederdi. Fakat ertesi günü meslek mahrumiyetine şeni' bir tecavüzü ve başkasına ait bir telgrafi neşr için gazeteyi iğfal ettiği tahakkuk edince -muharrir kelimesinin kadrini tezlil etmeyelim- o nesneyi derhal kapı dışarı atar ve bunu hakkına hürmet isteyen bir gazeteye karşı açıkça yazarak: "Bu yapılan iş meslek namına lekedir, onu tamir ediyor, bu adamı kovuyorum" derdi. Vakit'in gerek meslek namına gerek dâhil olduğu maşer-i milli namına uhdesine düşen ahlaki vazife buydu.

Heyhat! Bizde kimden bahsediyoruz. Sabah'tan değil mi?". ${ }^{31}$

\footnotetext{
${ }^{30}$ Henri Désiré Landru, 20. yüzyıl başlarında Fransa'da idam edilen bir seri katildir. Landru evlenme vaadiyle kandırdığı 10 kadını çeşitli zamanlarda balta ve testere ile parçalayarak öldürmüş daha sonra sobada yakmıştır. Bunun yanında cinayetlerini öğrenen bir erkeği de öldürmüştür. Mahkemede yargılanan Landru 25 Şubat 1922'de idam edilmiştir. http://www.almanaktr.com/index.php/dunya-1920-1929/100duenya-1922/454 (11.06.2017)

31 "Şecaat Arzederken-Merd-i Kıpti Sirkatin söyler, demişlerdi. Peyam- Sabah ise sirkatini söylerken şecaat arz ediyor", Vakit, 1433, 6 Kanun-1 evvel 1921, s. 2.
} 


\section{SONUÇ}

İkinci Meşrutiyet'in ilanından sonra Osmanlı Devleti'nde deyim yerinde ise bir basın patlaması yaşanmış ve birçok gazete ve dergi yayın hayatına girmiştir. Belirtilen dönemde Osmanlı Devleti'nde haber ajanslarının yetersizliği gazete ve dergilerin kendi imkânlarıyla haber toplamalarını gerekli kılmıştır. Bu nedenle gazeteler muhabirlerinin getirdikleri haberler yanında diğer gazeteleri de tarayarak atladıkları veya atlatıldıkları haberleri buralardan temin etme yoluna gitmişlerdir. O tarihlerden gazetelerin akşam veya sabah gazetesi olarak çıkmaları da bu işi kolaylaştırmıştır.

Gazetelerin 1910 yılına kadar birbirlerinden kaynak göstermeden haber alabilmelerini kolaylaştıran unsurlardan biri de telif hakları konusundaki hukuki boşluktu. 1910 yılında yasalaşan Telif Kanunu ile gazetelerden alınan haberlerde kaynak gösterme zorunluluğu getirilmiştir. Buna rağmen gazeteler birbirlerinden kaynak göstermeden haber almaya devam etmişlerdir. Ancak her gazete bu durumda şikâyet etmemiş ise de zaman zaman bu işten rahatsız olan gazeteler de olmuştur. Bizim tespit edebildiğimiz kadarıyla Osmanlı Basın Tarihinde bu konuyla ilgili üç tartışma yaşanmıştır. Bunların birincisi Tanin ile Sabah arasında, ikincisi Ikdam ile yine Sabah arasında, üçüncüsü ise Vakit ile Peyam-ı Sabah arasında yaşanmıştır. Bu üç hadise gazeteler arasında yapılan bir tartışma ve teşhir şeklinde kalmış, hukuki bir süreç yaşanmamıştır.

\section{KAYNAKÇA}

\section{I- Kitap ve Makaleler}

-Çakmak, Diren, "Osmanlı Telif Hukuku ile İlgili Mevzuat", Selçuk Üniversitesi Türkiyat Araştırmaları Dergisi, Sayı: 21, Konya 2007, s. 191-234.

-http://www.almanaktr.com/index.php/dunya-1920-1929/100-duenya-1922/454

(11.06.2017)

-Koloğlu, Orhan, Osmanlı Döneminde Basın Teknikleri ve Araçları, İstanbul 2010.

-Seçim, Filiz-Turhan, Seyfettin, Haber Ajanslarl, Eskişehir 1994.

-TBMM Zabit Ceridesi, Cilt: 14, Ankara 1958.

-Topuz, Hıfzı, 100 Soruda Türk Basın Tarihi, İstanbul 1996.

-Yalçın, Hüseyin Cahit, Edebiyat Anıları, İstanbul 1975.

-Yalçın, Hüseyin Cahit, Meşrutiyet Hatıraları 1908-1918”, Fikir Hareketleri, Sayı: 177, 13 Mart 1937.

\section{II- Süreli Yayınlar}

-İkdam

-Peyam-1 Sabah

- Sabah

-Tanin

-Tasvir-i Efkâr

-Tercüman-1 Hakikat

-Vakit 